\title{
RESISTÊNCIA COTIDIANA À AGROINDÚSTRIA DO DENDÊ EM UMA COMUNIDADE QUILOMBOLA RURAL NA AMAZÔNIA ORIENTAL
}

\author{
Heribert Schmitz $ه$ \\ Universidade Federal do Pará I Belém - PA - Brasil
}

Lissandra Cordeiro Ribeiro (D) $\triangle$

Universidade Federal do Pará | Belém - PA - Brasil

Dalva Maria da Mota $ه$

Embrapa Amazônia Oriental I Belém - PA - Brasil 
O objetivo deste artigo é analisar como os moradores da comunidade quilombola rural do Castanhalzinho, em Concórdia do Pará, desenvolvem formas de resistência cotidiana à agroindústria do dendê. A metodologia constou de estudo de caso com observação participante e entrevistas (semiestruturadas e abertas) com membros de todas as famílias do local. Concluímos que as principais formas de resistência foram a negação de venda das terras para a agroindústria, com uma manifestação aberta de associações quilombolas, a rejeição das regras de assalariamento nos plantios empresariais, o discurso sobre os efeitos do dendê e a persistência no acesso aos recursos na reserva legal da empresa, anteriormente público. A resistência cotidiana baseia-se na coesão do grupo, sustentada pela reciprocidade, pela religiosidade, pelo parentesco e pela autonomia no trabalho e objetiva a manutenção do território sem submissão aos efeitos da dendeicultura e aos mecanismos de dominação de grupos mais poderosos.

Palavras-chave: palma de óleo; quilombo; agroindústria; Amazônia

\section{EVERYDAY RESISTANCE TO OIL PALM AGROINDUSTRY IN A RURAL QUILOMBOLA COMMUNITY IN THE EASTERN AMAZON}

\section{ABSTRACT}

The objective of this article is to analyze how the residents of the rural quilombola community of Castanhalzinho, in Concórdia do Pará, develop everyday forms of resistance to the oil palm industry. The methodology consisted of a case study with participant observation and semi-structured and open interviews with members of all local families. We conclude that the main forms of resistance were the denial of sale of land to the agroindustry, which included an open manifestation of quilombola associations, the rejection of the rules of wages in plantations, the discourse on the effects of palm oil cultivation and the persistence of access to resources in the reserve of the company, previously public. The everyday resistance is based on the cohesion of the group supported by reciprocity, religiosity, kinship and autonomy at work and aims at the persistence in the territory without submission to the effects of the palm oil cultivation and the mechanisms of domination by more powerful groups.

Keywords: oil palm; quilombo;

\section{RESISTENCIA COTIDIANA A LA AGROINDUSTRIA DE PALMA ACEITERA EN UNA COMUNIDAD RURAL QUILOMBOLA DEL ESTE DE LA AMAZONÍA}

El objetivo de este artículo es analizar cómo los residentes de la comunidad rural quilombola de Castanhalzinho, en Concórdia do Pará, desarrollan formas cotidianas de resistencia a la industria de la palma aceitera. La metodología consistió en un estudio de caso con observación participante y entrevistas semiestructuradas y abiertas con miembros de todas las famílias locales. Concluimos que las principales formas de resistencia fueron la negación de la venta de tierras a la agroindustria, que incluyó una manifestación abierta de las asociaciones de quilombolas, el rechazo de las reglas salariales en las plantaciones, el discurso sobre los efectos del cultivo de palma aceitera y la persistencia. de acceso a recursos en la reserva de la empresa, previamente públicos. La resistencia cotidiana se basa en la cohesión del grupo apoyada por la reciprocidad, la religiosidad, el parentesco y la autonomía en el trabajo y apunta a la persistencia en el territorio sin someterse a los efectos del cultivo de la palma aceitera y los mecanismos de dominación por parte de grupos más poderosos.

Palabras clave: palma aceitera; quilombo; 


\section{INTRODUÇÃo}

$\mathrm{O}$ artigo tem como objetivo analisar como os moradores de uma comunidade quilombola desenvolvem formas de resistência à agroindústria do dendê no nordeste paraense (NEP). O cultivo do dendê na Amazônia paraense existe desde o final da década de 50 do século XX - experiências anteriores tinham caráter experimental -, porém ganhou intensidade com o Programa Nacional de Produção de Biodiesel (PNPB), criado pelo Governo Federal em 2004 para fomentar a produção de combustíveis alternativos ao petróleo a partir do óleo de dendêt $\hat{e}^{1}$ prevendo a criação de empregos assalariados e a inclusão da agricultura familiar por meio de contratos de produção (Brasil 2010).

A dendeicultura foi apresentada à população do NEP por uma frente ampla formada por representantes de instituições públicas, da mídia, das empresas e lideranças como a solução para o desemprego e a baixa renda na agricultura familiar, bem como sob o argumento de recuperação de áreas "degradadas" e da oferta de um futuro sustentável para a região, na perspectiva de uma economia verde. A introdução da dendeicultura contou com o esforço pessoal do presidente Lula, que lançou, em 2010, o Programa de Produção Sustentável da Palma de Óleo (PPSPO), em Tomé-Açu, cidade vizinha de Concórdia do Pará, onde foi realizada a pesquisa. Para conquistar a adesão de agricultores familiares à produção do dendê nas suas propriedades sob o sistema de integração às agroindústrias ${ }^{2}$, foram desenvolvidas estratégias de recrutamento ("captação"), com o envolvimento de lideranças das organizações sociais e de técnicos de instituições governamentais (das esferas nacional, estadual e municipal), que enfocaram nesse processo de persuasão o aumento da renda e a melhoria da qualidade de vida, sempre fazendo comparações com a situação anterior (Guedes 2014).

Em 2010, com a chegada de uma grande empresa, reunindo agroindústria e plantation, ao município de Concórdia do Pará, intensificou-se a compra de terras, paralelamente a posicionamentos contrários de organizações sociais, especialmente de associações quilombolas afetadas pela ação da agroindústria (Backhouse 2013; Macedo \& Sousa 2015).

Com a implantação do monocultivo na área da empresa, houve a modificação da configuração espacial, o que teve influência nas relações dos

1 Outros autores usam a expressão "óleo de palma”. Trata-se do óleo dos frutos do dendezeiro (Elaeis guineensis), planta também conhecida como palma de óleo.

2 Aquino (2013:46) entende a "integração produtiva como uma maneira de inserção competitiva da pequena propriedade, fundamentada na mão de obra familiar, no agronegócio exportador. Tal apontamento considera o volume de recursos gerados pelas exportações das cadeias produtivas onde a integração acontece”. 
moradores de Castanhalzinho com o novo "vizinho", no que se refere à liberdade do uso dos recursos naturais e à mobilidade na área do entorno da comunidade. De maneira mais acentuada, Acevedo Marin \& Backhouse (2014) falam de "guerra do dendê", referindo-se aos quilombolas atingidos pela expansão do dendê no Pará. Não obstante, segundo Backhouse (2013:6), "a ampla legitimidade concedida à exploração agroindustrial [...] dificulta a oposição ou resistência ao Programa de Produção Sustentável de Óleo de Palma”. A autora continua: "Neste contexto, reivindicações por parte dos agricultores familiares, bem como resistência política são dificultadas pela cada vez mais acentuada assimetria de poder na região" (Backhouse 2013:25). No entanto, registram-se também confrontos abertos contra a atividade por meio da ocupação das instalações de empresas de dendê por índios e quilombolas em Acará e ToméAçu, municípios vizinhos de Concórdia do Pará, em 2014 e 2015 (Silva et al. 2016; Thury 2017).

Em âmbito mundial, a literatura registra resistências da população nativa à produção de dendê, como na Indonésia ${ }^{3}$, onde se constatou o desmatamento de extensas áreas de terras para o cultivo da palmeira (Norwana et al. 2011; Schrier-Uijl et al. 2013). Sirait (2009) destacou que a produção empresarial de dendê em monocultivo ocasionou problemas à comunidade indígena de Kalimantan, como o fracionamento de terras, fazendo com que os grupos étnicos migrassem em busca de novos territórios. Potter (2008), em estudo em Kalimantan Ocidental, verificou práticas de resistência à dendeicultura pelos Dayaks ${ }^{4}$, com embates abertos, que culminaram com o fechamento de estradas, a destruição de culturas agrícolas e a queima de máquinas. $\mathrm{O}$ autor mostrou que na região alguns moradores não aceitavam ceder suas terras para o cultivo da palmeira, mesmo com forte coação do governo local. Ao contrário, preferiam trabalhar em atividades tradicionais de arroz e de extração da borracha. Mesmo quando forçados, pela queda nos preços da borracha na crise financeira de 2002, a cultivar o dendê, houve formas de resistência abertas e silenciosas contra as empresas dendeicultoras. Num sistema misto de produção própria e assalariamento numa grande empresa, práticas como furtos de insumos para revenda em outro lugar e a lentidão ou falta no trabalho foram comuns.

A resistência de um grupo ao outro nem sempre acontece por meio de embates abertos e de conflitos declarados, especialmente quando se trata de uma

3 A Indonésia é hoje o maior produtor de dendê no mundo, a Malásia está no segundo lugar. Segundo uma estimativa de 2018 do United States Department of Agriculture (USDA 2020), esses dois países juntos são responsáveis por 84,2\% da produção mundial.

4 Segundo Potter (2008:1), “Dayak’ é o termo genérico dado a grupos indígenas em Kalimantan, Bornéu indonésio" [Todas as traduções de línguas estrangeiras neste artigo foram feitas pelos autores]. 
relação de poder muito desigual, como mostra Scott (1985), a partir de um estudo na Malásia, onde o autor observou uma resistência cotidiana dos agricultores locais aos grandes fazendeiros numa importante região produtora de arroz.

A crítica ao desmatamento pela produção do dendê e a resistência de comunidades indígenas em países como a Indonésia alertaram o governo brasileiro, que criou marcos regulatórios por meio do PNPB, do PPSPO, do Zoneamento Agroecológico do Dendê para as Áreas Desmatadas da Amazônia Legal (ZAE-Dendê) e da tentativa de adoção de um Protocolo de Intenções Socioambientais da Palma de Óleo do Estado do Pará ${ }^{5}$, para evitar a repetição dessas experiências. Foram introduzidas no regulamento, especialmente, a proposta da participação da agricultura familiar na oferta de matéria-prima e a proibição da supressão de vegetação nativa para o plantio de dendê.

Nesse contexto, a pesquisa foi realizada com o objetivo de analisar como uma comunidade rural de quilombolas desenvolve formas de resistência à introdução da dendeicultura. A pergunta a ser respondida é: como se evidenciam as formas de resistência dos moradores da comunidade quilombola de Castanhalzinho à agroindústria do dendê? A metodologia baseou-se em pesquisa qualitativa, por meio de estudo de caso realizado em 2015 (julho) e 2016 (maio, junho, setembro), com observação participante e entrevistas abertas e semiestruturadas. As entrevistas ${ }^{6}$ foram realizadas com membros de todas as 27 famílias que vivem na comunidade. Três critérios orientaram a escolha de Castanhalzinho para o estudo: i) situa-se em uma região com muitas comunidades quilombolas que não constam no ZAE; ii) está cercado pelos dendezais e com grande movimento de compra e venda de terras nos arredores; iii) evidencia-se pela resistência para persistir no território.

\section{FORMAS DE RESISTÊNCIA COTIDIANA}

Tomamos como suporte teórico as reflexões de Scott (2013), considerando as semelhanças entre o caso estudado pelo autor na Malásia e a reação de quilombolas no NEP à agroindústria do dendê. A análise das "formas cotidianas de resistência” por Scott deu-se a partir de vários anos de pesquisa em uma aldeia chamada Sedaka, localizada na planície de Muda, uma importante região da Malásia que produz arroz. Seu objeto de estudo foi a reação dos camponeses à Revolução Verde, voltada para o aumento da produtividade

5 O PNPB e o PPSPO foram lançados pelo governo federal em 2005 e 2010, respectivamente. O Protocolo foi assinado em 26 de agosto de 2014 por órgãos do Estado, a Abrapalma, a Federação da Agricultura do Estado do Pará e o Serviço Nacional de Aprendizagem Rural.

6 As entrevistas tinham uma duração média de duas horas. 
por meio de mudanças tecnológicas na produção do arroz. Tal iniciativa ocasionou desemprego, aumento das desigualdades e dependência dos pequenos agricultores dos arrendatários de terras. Os agricultores recorreram a práticas cotidianas, como pequenos furtos, boicotes ou lentidão no trabalho e a discursos de negação como formas de resistência à situação imposta (Scott 2013).

James Scott lança luz sobre as formas de resistência cotidiana de "subordinados" em relação aos que os dominam, que não buscam, porém, o caminho da organização em movimentos sociais e da disputa aberta. O autor critica a ideia de atribuir uma "falsa consciência" aos subordinados e destaca que as formas aparentes de aceitação perante quem exerce a dominação representam uma estratégia de resistência disfarçada, como resposta à situação de subordinação (Scott 2013).

Os discursos " [...] orientam as interações cotidianas entre dominantes e dominados" (Menezes 2002:34). Scott (2013) faz uma distinção entre discurso público e discurso oculto. O primeiro estaria ligado ao agente dominador - normalmente não é relacionado ao subordinado que não rompe o silêncio - e, por vezes, caracteriza-se por um tom conciliador e a justificativas palpáveis para a hegemonia dos valores dominantes, uma "[...] forma abreviada de designar as relações explícitas entre subordinados e os detentores do poder" (Scott 2013:28). O discurso oculto, por sua vez, não se caracteriza por manifestações tão claras e comuns como o discurso público. É aquilo que não é dito na presença do poder. "O discurso oculto constitui, por esta razão, o lugar privilegiado para o desenvolvimento de uma linguagem não hegemônica, contraveniente, dissidente, subversiva” (Scott 2013:57).

O discurso oculto faz parte da ação de um grupo de indivíduos que geralmente são afetados pelos mesmos problemas. Elementos como dignidade, justiça, negação, espaço social reservado e disfarce político compõem o discurso oculto. Scott (2013) preocupa-se em deixar claro que o discurso oculto não se restringe a queixumes e lamentações, e exemplifica que este elemento enquanto prática, por exemplo, no caso de escravos, pode caracterizarse pela caça clandestina, pela falta de empenho no trabalho, pela negligência, pela sabotagem, pela evasão etc. Os grupos subordinados fazem uso desse discurso criando uma subcultura de resistência, contrapondo-se, dessa maneira, à dominação social exercida pela elite dominante.

O discurso oculto é o que vai construir a resistência cotidiana, a infrapolítica dos subordinados. A infrapolítica deve ser compreendida no sentido não de inferior às lutas e manifestações abertas, mas de resistência discreta, como os raios infravermelhos, que não estão visíveis a olho nu. A Figura 1 explicita os principais elementos presentes no discurso oculto dos subordinados. 


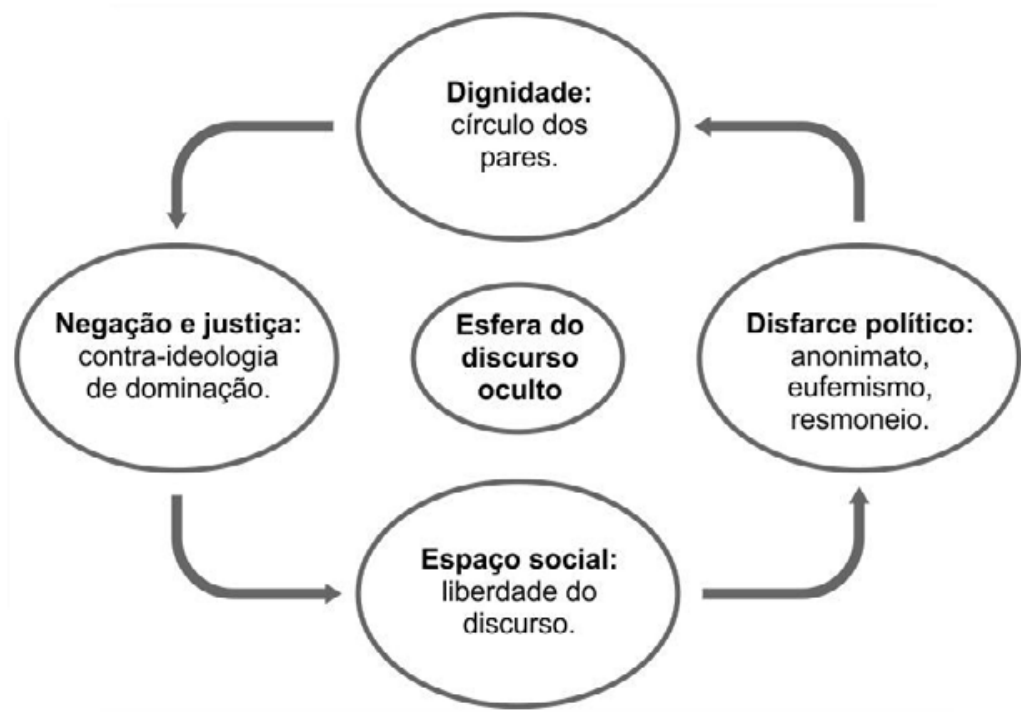

Figura 1 - Discurso oculto: dignidade, negação e justiça: produção de uma subcultura de resistência. Fonte: Scott (2013). Adaptação dos autores.

O discurso oculto é específico de um determinado grupo social, de um grupo particular de atores, e não abrange somente atos discursivos, mas compreende um conjunto de práticas diversas. "O discurso oculto representa, por definição, a linguagem - os gestos, discursos, práticas - que é normalmente excluída do discurso público dos subordinados pelo exercício de poder" (Scott 2013:60).

A análise das formas cotidianas de resistência permite compreender a política de grupos subalternos para além da noção de hegemonia ou de conformismo e passividade, na qual normalmente são pensadas. Mas é preciso questionar se essas formas de resistência apenas amenizam a indignação a que indivíduos e grupos estão submetidos, não alterando, substancialmente, as relações de dominação. "Uma forma de enfrentar as ambiguidades das práticas cotidianas é analisar tanto as consequências sobre a reprodução quanto sobre as transformações das relações de poder" (Menezes 2002:43). É a partir desse olhar que analisamos como os moradores da comunidade do Castanhalzinho desenvolvem formas de resistência à agroindústria do dendê. Considerando a relação entre dominantes e subordinados, buscamos salientar as estratégias que os dois grupos utilizam para a conquista de seus interesses.

\subsection{RESISTÊNCIA DE UM CAMPESINATO NEGRO NA AMAZÔNIA}

Desde o início da escravidão negra, a partir da captura na África, há relatos de resistência (Treccani 2006). Nos quase 400 anos de escravidão, Florentino \& Amantino (2012:237) identificam as fugas e os quilombos como "[...] a típica atitude de resistência à escravidão, um ato extremo no campo da política, cuja simples possibilidade apontava para os limites do domínio privado do senhor [...]”. Os autores afirmam que as fugas muitas vezes não foram definitivas, mas tiveram o objetivo de negociar melhores condições na escravidão. Sobre a resistência cotidiana, encontramse menos documentos: 
Onde houve escravidão houve resistência. E de vários tipos. Mesmo sob a ameaça do chicote, o escravo negociava espaços de autonomia com os senhores ou fazia corpo mole no trabalho, quebrava ferramentas, incendiava plantações, agredia senhores e feitores, rebelava-se individual e coletivamente (Reis \& Gomes 1996:9).

Segundo Cueva (2011:221), formou-se, na Amazônia, um campesinato negro por dois motivos: "por um lado, o impulso dos escravos para transformar suas vidas cotidianas e criar comunidades rurais autônomas e, por outro, a evolução da economia regional”. Em torno de 1870, os principais produtos da próspera economia das regiões, que se basearam mais no trabalho escravo e na exportação da borracha, entraram em declínio (com exceção do cacau), e os investimentos dirigiam-se para outras atividades, como criação de gado e imóveis urbanos. A oportunidade criada pela retirada dos antigos donos das plantações foi reforçada pela abolição final, em 1888, o que levou "[...] muitos libertos a permanecer nas propriedades onde haviam trabalhado e residido há décadas". Nessa época, os escravos paraenses já tinham aprendido e posto em prática "[...] as bases econômicas, sociais e culturais de uma comunidade de caboclo" (Cueva 2011:222) ${ }^{7}$.

A maior expressão da resistência aberta do campesinato negro no Pará foi a sua participação na Cabanagem, uma revolta ou guerra civil entre 1835 e 1841, que envolveu principalmente "[...] pobres camponeses de origem étnica mista que viviam em cabanas perto dos rios, daí o nome de cabanos” (Cueva 2011:46). Cleary (1998:113) destaca que "[...] a rebelião foi percebida como uma revolta geral de gente de cor $[\ldots]$ ".

O marco temporal do reconhecimento jurídico dos quilombolas, no Brasil, foi o artigo constitucional de 1988 que previa a concessão de títulos aos quilombolas ${ }^{8}$. A partir desse momento, houve uma grande articulação dos movimentos sociais para que as terras fossem de fato tituladas. Comunidades quilombolas de diversos estados do país organizaram-se pela garantia do direito.

Em abril de 1995, nasceu no Maranhão a Coordenação Estadual dos Quilombos Maranhenses, que estimulou a formação de coordenações estaduais em Pernambuco, Piauí, Espírito Santo e Minas Gerais. A Coordenação

7 Contribuiu para isso o que Cardoso (1982 [1979]) chama "a brecha camponesa no sistema escravista", expressão cunhada por Tadeusz Lepkowski, que indica, além da produção independente de escravos fugidos, a produção agrícola (vegetal e animal) em "[...] pequenos lotes de terra concedidos em usufruto, nas fazendas, aos escravos não domésticos [...]” (Cardoso 1982 [1979]:133). Esse fenômeno foi constatado também no Pará (Linhares \& Silva 2009 [1981]).

8 O artigo 68 do Ato das Disposições Constitucionais Transitórias (ADCT) da Constituição Federal de 1988 afirma: "Aos remanescentes das comunidades dos quilombos que estejam ocupando suas terras é reconhecida a propriedade definitiva, devendo o Estado emitir-lhes os títulos respectivos" (Brasil 1988). 
Estadual das Comunidades Negras do Pará (Malungu) foi criada em março de 2004. Um mapeamento no Pará identificou 396 comunidades quilombolas em 46 municípios paraenses (Treccani 2006). A maioria das áreas quilombolas (58\%) encontra-se na mesorregião NEP (cálculo dos autores com base em Malcher 2017).

Na região de Concórdia do Pará e dos municípios vizinhos, a mobilização para o reconhecimento quilombola deu-se a partir dos trabalhos desenvolvidos pelos "Círculos de Cultura" da Comissão Pastoral da Terra (CPT) - Guajarina e dos debates ocorridos nos grupos de evangelização das comunidades de Bujaru', a partir de 1972. Um intenso trabalho de evangelização e de formação e organização políticas nas comunidades rurais, fortemente influenciado pela teologia da libertação, criou a cultura política necessária à formação da Associação das Comunidades Remanescentes de Quilombos Oxalá de Bujaru (Arquiob) (Malcher 2011).

A comunidade do Castanhalzinho, junto com as comunidades do Cravo, Perpétuo Socorro, Velho Expedito e Curuperé, é representada pela
Associação de Remanescentes Quilombolas do Cravo (Arquic) ${ }^{10}$. Essas comunidades são reconhecidas pela Fundação Cultural Palmares (FCP 2020) como quilombolas. A certidão de reconhecimento da área quilombola foi emitida em 2006, porém a titulação ainda não foi concretizada ${ }^{11}$, como aconteceu com outras áreas localizadas no município. Com a certidão, os moradores tiveram acesso a políticas públicas para grupos identificados como remanescentes de quilombos, como o Programa Minha Casa, Minha Vida e o Bolsa Família. Mas, por falta da titulação, a área fica ainda muito vulnerável a tentativas de fragmentação.

\section{A COMUNIDADE CASTANHALZINHO, A LUTA PELA TITULAÇÃO QUILOMBOLA E A EXPANSÃO DA AGROINDÚSTRIA DO DENDÊ}

O município de Concórdia do Pará encontra-se na microrregião de Tomé-Açu, no NEP, a 150 km de Belém, e possuía uma população estimada de 33.318 habitantes, em 2019, e uma área de 700,59 $\mathrm{km}^{2}$ (IBGE 2020). O NEP é a região da expansão do

9 Até 1988, Concórdia do Pará foi uma vila pertencente ao município de Bujaru. Nesse ano, obteve sua emancipação política e administrativa, tornando-se município.

10 A criação da Arquic resultou da ruptura com uma associação criada anteriormente, a Associação de Remanescentes de Quilombo de Nova Esperança de Concórdia (Arquinec), que englobava, até 2011, as comunidades que hoje fazem parte da Arquic e mais quatro comunidades: Dona, Ipanema, Santo Antônio e Campo Verde.

11 Castanhalzinho (Timboteua Cravo) está certificado pela FCP pela Portaria n. ${ }^{\circ} 29 / 2006$, publicada no Diário Oficial da União no dia 13 de dezembro de 2006, mas não há ainda o Relatório Técnico de Identificação e Delimitação (RTID) do Instituto Nacional de Colonização e Reforma Agrária (Incra). 
dendê, onde se destaca a microrregião de ToméAçu, com $81 \%$ das áreas plantadas (Brandão \& Schoneveld 2015). Nessa mesma microrregião, encontram-se 48 comunidades quilombolas ${ }^{12}$, que estão lutando pela sua titulação definitiva. A comunidade do Castanhalzinho (Figura 2) está localizada ao lado direito do $\mathrm{km} 35$ na rodovia PA-140, no limite entre os municípios de Bujaru e Concórdia do Pará, tendo como fronteira o igarapé Cravo, afluente do rio Bujaru ${ }^{13}$.

A comunidade é composta por 27 famílias, que moram dispersas ao longo de três ramais ${ }^{14} \mathrm{e}$ consideram a sua terra como propriedade privada. A maioria das casas (15) é de madeira, cinco são de taipa e, em 2013, foi iniciada a construção de sete casas de alvenaria por meio do Programa Minha Casa, Minha Vida, do Governo Federal.
O espaço produtivo abrange a roça ${ }^{15}$ e o retiro (casa de farinha) onde se produz a farinha de mandioca. Ao longo do ano, são realizadas duas roças, as chamadas roças de inverno (dezembro/ janeiro) e as de verão (junho/julho). A maioria das culturas anuais é plantada no inverno (milho, arroz, mandioca) por conta da certeza de haver chuvas. A roça de verão inclui a mandioca e o feijão. A mandioca é um produto estratégico para a reprodução das famílias ${ }^{16}$, pois a farinha constitui o elemento básico para o consumo alimentar e para a comercialização. Entre as culturas perenes, encontra-se a pimenta-do-reino, que representa uma possibilidade maior de renda. Além desses produtos, a dieta alimentar dos moradores baseiase em frutas, como mamão, banana, coco, manga, pupunha, e em proteína animal (porcos e galinhas).

12 Segundo dados da Fundação Cultural Palmares (FCP 2020), 23,3\% das 206 comunidades quilombolas do Pará estão localizados nessa microrregião. Considera-se o Pará como o estado com o maior número de comunidades quilombolas reconhecidas (Pará 2018; Peabiru 2020). Atualmente, 62 áreas no Pará são tituladas (CPISP 2020). Por vários motivos, a identificação das áreas quilombolas é difícil, como explica Malcher (2017). Segundo a autora, existem 324 áreas quilombolas autoidentificadas no Pará, sendo 269 certificadas e 136 tituladas, indicando entre as fontes a página do Incra. Em julho de 2020, essa página não oferece essas informações, impossibilitando a verificação desses números.

13 O rio Bujaru é o principal rio que banha os municípios de Bujaru e Concórdia do Pará, tendo sido importante no processo de ocupação ainda no século XVIII, cujo ponto de ocupação foi a Freguesia de Santana. Ao longo do curso do rio Bujaru, foi desenvolvida uma rede de comunidades rurais que, no decorrer do tempo, constituíram uma base territorial camponesa. Dentre as comunidades mais importantes, destacam-se Santana, São Judas, Santo Antônio, Cravo, Arapiranga, entre outras (Sousa \& Macedo 2011). O igarapé Cravo é um dos principais afluentes do rio Bujaru. Com a emancipação político-administrativa do município de Concórdia do Pará em relação ao município de Bujaru, esse igarapé tornou-se uma linha divisória entre os dois municípios.

14 Na região de estudo, estradas secundárias, muitas vezes de chão e sem saída.

15 Roça é uma denominação utilizada na agricultura familiar da Amazônia caracterizada pelo uso de uma área de um a dois anos, seguidos por vários anos de pousio no sistema de "corte e queima".

16 Para Almeida (1986), a família refere-se a um grupo de pessoas que são vinculadas a priori por parentesco. Em muitos casos, os vínculos de parentesco e de residência coincidem e estruturam certo modo de organização social em que a gestão e o trabalho estão imbricados (unidade de consumo e unidade de trabalho). 


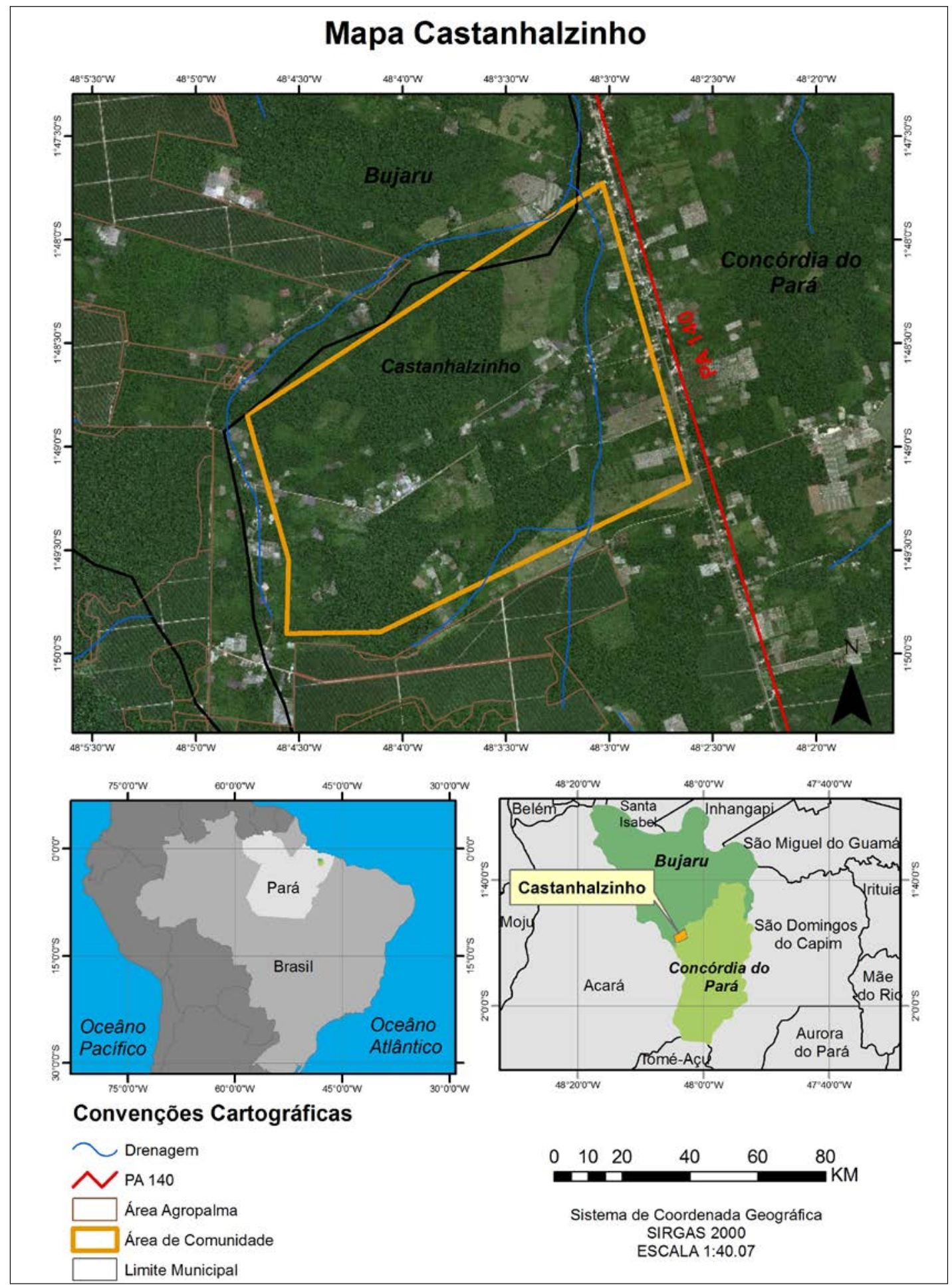

Figura 2 - A comunidade de Castanhalzinho, em Concórdia do Pará.

Fonte: elaborado por Rafael Benevides de Sousa (Unifesspa) e pelos autores. 
Os primeiros residentes de Castanhalzinho vieram da comunidade do Cravo, subindo o igarapé Cravo até a nascente, em busca de novas áreas de terra onde pudessem sobreviver. Uma das mais antigas moradoras da localidade explica:

Só que quando meus pais vieram com o
tio Noé pra cá, eles só pegaram dois lotes,
quer dizer que já tinha gente lotado aqui,
cearenses, tudo, estava tudo cheio por
aqui. Irmã, já tinha tanta gente aí, tanta
família. Eram de Capanema, do Ceará,
não sei de onde, não sei de onde, eles
trabalharam muito tempo aí, produziam
muito sabe? (E. F., 70 anos, aposentada,
comunicação pessoal, 2016).

A informação de E. F. sobre a mobilidade dos que buscavam terra coincide com a análise de Tavares (2008) da atração que exerceu a construção da rodovia Belém-Brasília para a criação de novas vilas e municípios na área. "Com a construção da Belém-Brasília, inicia-se uma maior mobilidade populacional para a Amazônia em busca de terras devolutas, sendo a mesma responsável pelo surgimento de dezenas de vilas, povoados e cidades" (Tavares 2008:71).

Os moradores antigos de Castanhalzinho enaltecem a fartura de caça e de frutos e a possibilidade de trabalhar, mesmo com a presença de outros atores de diversos lugares que se apossaram de maiores áreas de terra. Porém, no decorrer do tempo "muitos foram se levantando e voltaram, foram embora, outros venderam, moram pela beira da estrada, tudo, né? Aí ficamos só nós aqui” (E. F., agricultora, comunicação pessoal, 2016). Os que ficaram são aqueles que possuíam dois ou três lotes e que constituíram uma organização social a partir de vínculos de parentesco, vizinhança e religiosidade.

E. F., nascida e criada na comunidade, possui vínculo direto com os demais moradores, que são seus filhos, netos e suas famílias. Outra família importante naquela organização social é a de C. D. e de D. E., sua esposa. Por meio do casamento de dois dos seus seis filhos, essa família está ligada à família de E. F.

Os laços de pertencimento evidenciam-se pela consanguinidade, mas também pela autodesignação de pertencimento. É o caso de A. B., moradora da comunidade há 38 anos, que não nasceu na região, mas, como ressalta, "não sou filha daqui, mas me considero" (A. B., 56 anos, agricultora, comunicação pessoal, 2016).

A organização social local estrutura-se com base nos laços de parentesco e de afinidade, o que faz com que haja uma coesão entre os que vivem no local. O parentesco amplia as possibilidades de reprodução da unidade familiar, pois há constantes trocas de alimentos, de roupas e também do trabalho na roça entre as famílias em redes de reciprocidade constituídas ao longo dos anos. Disse um morador quando lhe perguntamos sobre o 
destino da produção: "a gente planta pra comer, pra vender, pra dar pro vizinho" (F. G., 30 anos, agricultor, comunicação pessoal, 2016). É comum não somente a troca de comidas, mas também empréstimos de ferramentas de trabalho e ajuda em situações de infortúnios, como doenças ou prejuízos sérios. Essas trocas ocorrem também com produtos comprados nos supermercados dos municípios de Concórdia do Pará ou Bujaru.

Até setembro de 2016, não havia energia elétrica na localidade; por isso, na dieta alimentar, constavam poucos produtos que dependem da conservação. Algumas casas possuíam geradores movidos à gasolina, que eram ligados principalmente à noite para as pessoas verem televisão. Esta situação mudou a partir da realização de um mutirão em prol do abastecimento de energia elétrica na comunidade. Os homens ficaram responsáveis pela limpeza dos ramais para facilitar a entrada do veículo com os postes e a fiação elétrica. As mulheres ficaram responsáveis pelo almoço e pela merenda dos homens durante esse trabalho. "Cada um deu uma coleta aí pra gente forrar o estômago, aí nós fizemos essa limpeza desses ramal tudinho, foi trabalho, mas rápido a gente terminou, pra ter essa energia, né?” (G. H., 44 anos, agricultor, comunicação pessoal, 2016).

Castanhalzinho é um lugar considerado tranquilo, mas sem grandes atrações para os jovens. Não há festas dançantes com "aparelhagem"17 e tampouco há balneários, muito apreciados por eles. Os jovens que querem esse tipo de lazer dirigem-se a comunidades próximas. Uma exceção é o campo de futebol que se configura como um lugar de lazer e de sociabilidade entre os moradores.

Em Castanhalzinho, como na maioria das vilas rurais da região, a comunidade divide-se também em católicos e evangélicos. Além da Igreja Católica, recentemente, a Igreja do Evangelho Quadrangular iniciou as suas atividades sob o incentivo de uma das moradoras mais antigas, E. F., que nasceu numa família católica e converteu-se por motivos pessoais há cerca de oito anos.

Vários autores destacam a religião como elemento-chave para a formação da identidade coletiva, da politização e da coesão das comunidades quilombolas no Pará, como explicam Macedo \& Sousa (2016:54):

[...] a religiosidade na vida camponesa
se caracteriza tanto como um
instrumento sagrado, de devoção a
santos, como um elemento que revigora
o sentimento de pertencimento a um
mesmo grupo social. Além disso, a
religiosidade em algumas comunidades
camponesas tem sido uma ferramenta
política de reivindicação de direitos
sociais e políticos.

Comparada com a Igreja Católica, a Igreja do Evangelho Quadrangular mantém uma rotina

17 No Pará, "aparelhagem" é o termo empregado para o aparelho de som utilizado nas festas. 
maior de encontros entre os membros (cultos, reuniões). O grupo dos evangélicos segue regras diferentes do grupo que frequenta a Igreja Católica. Tantos os homens como as mulheres não podem frequentar festas, nem ingerir bebidas alcoólicas. Isso ocasiona muitas vezes repartições intrafamiliares: há casos de famílias em que a esposa é evangélica e o esposo católico, ou o contrário. Por isso, E. F. expõe o sonho e o esforço que tem feito para que os filhos e os netos também se convertam:

Irmã, olha eu oro tanto para que eles aceitem Jesus, porque eles se dizem católicos, mas, irmã, eles não são de orar lá na frente, de falar uma palavra do Senhor, de profetizar. Eles vão, ouvem o que o dirigente está dizendo lá na frente, depois vão embora e pronto. Não vivem aquela fé, sabe? (E. F., 70 anos, aposentada, comunicação pessoal, 2016).

Podemos constatar que, nos últimos tempos, os grupos evangélicos assumiram o protagonismo na vida religiosa e os seus líderes tentam atrair mais e mais fiéis, o que gera conflitos em algumas famílias compostas por membros católicos e evangélicos. Mesmo assim, a divisão religiosa não se tornou um problema para a coesão da comunidade na sua resistência, porque os grupos se reconhecem pela origem e as relações de parentesco são muito fortes, especialmente pela posição central de E. F.

Em Castanhalzinho, todos - evangélicos e católicos - adotam a identificação quilombola, que é considerada e reconhecida pelos moradores também como uma forma de acesso às políticas públicas. A identidade coletiva, segundo Eder (2003), pode emergir de laços fortes por meio da pertença a um grupo, mas pode também se basear em laços fracos por meio dos interesses econômicos. Apesar das divergências internas nas famílias, a oposição à dendeicultura uniu-os e reforçou a formação de um grupo coeso na sua resistência cotidiana contra o dominante.

\section{RESISTÊNCIA COTIDIANA EM CASTANHALZINHO}

A instalação da empresa mencionada aconteceu no ano de 2009 e, no decorrer dos últimos anos, ela aumentou os investimentos para o plantio próprio e intensificou a relação com agricultores familiares por meio da integração por contrato18. A empresa dispõe de aproximadamente 56.000 hectares de dendezeiros plantados em terras próprias e de cerca de 6.000 hectares em contrato com agricultores familiares, além de oferecer 4.527 postos de trabalho (Brandão \& Schoneveld 2015). Mesmo

18 A empresa fechou um contrato de integração produtiva com agricultores familiares “[...] nos municípios de Acará, Abaetetuba, Aurora do Pará, Barcarena, Bujaru, Concórdia do Pará, Igarapé-Miri, Moju, Mocajuba, São Domingos do Capim e Tomé-Açu" (Sampaio 2014:89). 
assim, registraram-se iniciativas de resistência à expansão da dendeicultura. Vários autores tratam da resistência, especialmente dos povos e comunidades tradicionais, contra as mudanças provocadas pela dendeicultura em grande escala no NEP (Malcher 2011; Pontes \& Guerra 2016; Saavedra 2017; Santana 2010; Sousa 2018; TimoneMartinez 2013).

Registros importantes mostram também que historicamente o campesinato negro está envolvido em disputas abertas nesta região, como é o caso da resistência dos quilombolas da comunidade de Jambuaçu, no município de Moju, Pará (Acevedo Marin 2010).

Para o caso específico dos quilombolas em Concórdia do Pará, houve dois momentos de resistência à expansão da dendeicultura. O primeiro diz respeito à mobilização das associações quilombolas para que houvesse um freio na apropriação de terras adquiridas pela agroindústria, no momento de intensa especulação fundiária. Nesse caso, houve uma resistência "[...] organizada, sistemática e cooperativa" (Scott 2002:25), fora da localidade. Por causa da transformação da paisagem em grande escala, sentida como uma ameaça ao modo de vida, e da preocupação com os impactos ambientais, a segurança alimentar e a vulnerabilidade da posse do território na região, as associações quilombolas no município de Concórdia do Pará - a Arquic e a Associação dos Remanescentes de Quilombos Nova Esperança de Concórdia (Arquinec) manifestaram-se contra a expansão das áreas sob cultivo de dendê das empresas e desenvolveram formas de resistência, a partir de 2009. O segundo momento coincidiu com o início das atividades da empresa, que engendrou novos arranjos no espaço físico: os moradores precisaram, então, desenvolver novas estratégias para continuar vivendo no local com as mudanças provocadas pelo plantio de dendê, a partir de 2010. "Para os camponeses, pulverizados ao longo da zona rural e enfrentando ainda mais obstáculos para a ação coletiva e organizada, as formas cotidianas de resistência parecem particularmente importantes" (Scott 2002:11) e são exatamente essas formas de resistência que analisaremos a seguir.

\subsection{RESISTÊNCIA CONTRA VENDA DE TERRAS E INTEGRAÇÃO À AGROINDÚSTRIA}

Segundo entrevistados, quando a empresa iniciou as atividades, seus interlocutores dirigiramse a Castanhalzinho e a outras comunidades quilombolas próximas, como Conceição do Guajará (município de Bujaru), para explicar as vantagens que a agroindústria traria para a região e para o local. Além da possibilidade de compra de terra, de emprego e de integração por contrato, a empresa 
propiciaria aos moradores a abertura de ramais e a assistência escolar aos alunos:

\begin{abstract}
Quando eles entraram aí, foi um discurso muito bonito, eles fizeram uma promessa com a gente, papel assinado numa reunião. O Sr. A., ele assinou que o povo da [empresa] ia ficar responsável para ele ficar dando manutenção era pros ramais, não é? Que ficava próximo da sede deles do dendê, que era pra eles poderem ficar entrando e saindo. Mas na verdade, isso não está acontecendo, porque eles acabam com a área que a gente anda, agora no deles eles consertam, metem máquina. Outra, eles falaram que na escola, que ele ia ficar também dando assistência, não é? Eles vinham mandar ajeitar o poço, botar água encanada, mas nada disso eles fizeram, então eu acho que para nós mesmos, para quem para pra pensar, esse dendê só veio para nos prejudicar (A. B., 56 anos, agricultora, comunicação pessoal, 2016).
\end{abstract}

O discurso dos interlocutores da empresa relatado por uma moradora nesse momento associa-se ao que Scott (2013) chama "discurso público do dominante": utiliza-se da afirmação da imagem de poder efetivo da empresa para produzir um discurso de ganho e de vantagens para os moradores do local. Nota-se, no entanto, na fala de A. B., uma insatisfação com as práticas desenvolvidas pela empresa; daí seu discurso de defesa da dignidade e da justiça. O fato de a empresa não cumprir as promessas feitas pelos interlocutores provoca uma fragilidade na afirmação da imagem de poder feita por ela anteriormente; por conseguinte, os moradores tendem a desacreditá-la e a reprová-la.

O discurso público é utilizado tanto pelo interlocutor, como pelos moradores. Se, no momento da reunião entre eles, os moradores não se mostraram contrários à atuação da empresa, isso não significa que eles mantêm uma postura de aceitação em relação aos efeitos provocados pela transformação do entorno da comunidade. Sobre isso, Scott (2013:31) explica:

Em termos ideológicos, o discurso público
tende, por força do seu tom conciliador, a
produzir justificações convincentes para
a hegemonia dos valores e do discurso
dominante [...] e qualquer análise feita
com base no discurso público tenderá
a concluir que os grupos subordinados
aceitam os termos de sua subordinação,
e que são parceiros voluntários [...] dessa
relação de forças.

Uma das formas de resistência em âmbito local foi a negação de venda das terras pelos quilombolas, mesmo com as ofertas dos interlocutores, que ofereceram quantias entre $\mathrm{R} \$ 15$ e $\mathrm{R} \$ 20$ mil reais por um lote ${ }^{19}$. Ainda no momento da pesquisa,

19 O termo "lote" está relacionado aos projetos de colonização agrícola no nordeste paraense promovido pelos governos central e provincial no século XIX, para substituir o trabalho escravo pelo trabalho livre de migrantes e garantir a produção e o abastecimento dos mercados do Pará e ocupar a área de floresta (Nunes 2009:71). Com o passar dos anos, os lotes foram adquiridos, parcialmente, por grandes e médios proprietários. Segundo um morador da comunidade do Castanhalzinho, um lote de terra tem $250 \mathrm{~m}$ de frente e 1.000 metros de fundo ( $25 \mathrm{ha}$ ), correspondendo a um módulo rural nessa região. 
quando perguntamos aos moradores: "Você pensou em vender sua terra?", a resposta vinha sempre acompanhada de um ar de negação e convicção: "Não, minha terra não vendo, não".

A empresa não conseguiu comprar terra, nem integrar agricultores da comunidade pelo sistema de contrato, mesmo com as ofertas feitas pelos interlocutores. A venda e a integração à agroindústria por contrato são elementos que, segundo um morador, colocam em risco a autonomia sobre a terra e o trabalho, logo, a própria reprodução da família:

Tiveram um tempo que vieram aí oferecer um dendê, mas aquele dendê era pra eles, não é? A gente ficava trabalhando e cultivando a terra, aí eles chegavam e levavam a plantação. Mas, e aí, como é que pode? Plantar dendê, só vai trabalhar naquilo. Diziam que dava pra ganhar 60 mil, mas eu disse não, minha família é grande, meus filhos têm família e onde é que a gente ia fazer uma rocinha pra comer uma farinha, não tem como. Eles disseram que dava pra fazer empréstimo e plantar o dendê, ele dava as mudas, fazia tudinho, mandava aradar as terras. Mas plantar só uma coisa, que o cabra nem pode comer. Por aqui nenhum colono aceitou (C. D., 61 anos, agricultor e aposentado, comunicação pessoal, 2016).

Da fala de C. D., deduz-se que a integração por contrato à empresa não se mostra interessante por dois motivos: por inserir-se em um campo pouco conhecido pelos agricultores, envolvendo regras e normas contratuais e transações financeiras de alto valor com um banco; por fazer os agricultores produzirem somente o dendê, colocando em risco a diversidade da produção. Resultados de pesquisa recente mostram que os receios são justificados. Segundo Brandão et al. (2018:5), “[...] a maioria dos agricultores $(54,8 \%)$ não consegue atender às expectativas de produtividade [...]" e corre o risco de tornar-se inadimplente.

Em Castanhalzinho, os lotes são considerados de propriedade privada; a terra não é um bem comunitário. A maioria dos moradores possui documento de compra da terra, e os que não possuem o título têm um recibo de compra. Para os moradores, a terra é a garantia da reprodução da família, não somente dos que trabalham no presente, o pai, a mãe e os filhos, mas também dos que trabalharão no futuro. $\mathrm{O}$ valor da terra para os moradores está associado diretamente ao trabalho, sobretudo à autonomia desse trabalho, que se estende à rede de parentesco e de vizinhança, e é manifestado pela partilha do que se produz, coleta ou caça. Mesmo considerando o fato de os lotes serem individuais, o prazer de estar e de morar junto, para além dos que residem na mesma casa, constitui um fator essencial para não vender a terra, como afirma uma das moradoras mais antigas: "se meus parentes fossem embora daqui, eu também ia” (E. F., 70 anos, aposentada, comunicação pessoal, 2016). 
A partir de outra referência empírica, Woortmann (1988) explica que se trata de uma campesinidade marcada pela associação intrínseca entre terra, família e trabalho, em que não se concebe o trabalho sem pensar na terra e na família. Essa campesinidade, porém, não é marcada somente por essas categorias, está também atrelada a valores e a princípios organizativos centrais, como a honra e a hierarquia. Trata-se de um tipo de sociedade que é oposta às sociedades modernas, individualizadas e voltadas para o mercado. Enquanto uma caracteriza-se por uma ordem moral, a segunda organiza-se por uma ordem econômica.

O desinteresse dos moradores pela venda da terra é associado também aos boatos sobre o arrependimento de quem a vendeu e foi embora para a cidade, seja Bujaru, seja Concórdia, e viu o dinheiro da venda rapidamente acabar. Essas pessoas tiveram de "trabalhar pra patrão", e, muitas vezes, esse patrão é a própria empresa.

Os diálogos, as conversas e as fofocas fazem parte de um discurso que abrange outros atores, principalmente aqueles agricultores que estão sob a influência efetiva da agroindústria, moradores de Castahalzinho e de comunidades de Bujaru e Concórdia do Pará. “[...] Grande parte dos boatos, dos olhares reprovadores e das comparações injustas [...] são justamente aquilo que ajuda a manter a unidade face à dominação exercida a partir do exterior" (Scott 2013:203).

A terra como valor para a reprodução familiar é fundamental, pois é principalmente a possibilidade de ter onde trabalhar que garante o retorno dos que saíram da comunidade em busca de "melhoria", como no caso de dois filhos de uma moradora que regressaram após perderem o emprego em Belém, em 2016. Eles voltaram à comunidade, ergueram casas e plantaram na área de terra da família.

Uma das moradoras mais antigas explicou-nos que "só os grandes" - os fazendeiros - venderam as terras do entorno de Castanhalzinho à empresa. Eles não moravam nessas propriedades e a terra servia para o cultivo da pimenta e para a criação de gado. Não havia, portanto, uma relação com o território, mas apenas uma relação mercantil com a terra, o que difere da situação dos moradores de Castanhalzinho, que vivem no local, sustentamse essencialmente da agricultura e estabelecem relações sociais no território.

\subsection{RESISTÊNCIA AO ASSALARIAMENTO: "DÁ AQUELE DINHEIRO TODO MÊS, MASÉ MAIS RUIM"}

Em 2010, dez moradores da comunidade trabalharam como assalariados na empresa, mas foram demitidos em menos de dois anos. No fim de 2016, somente três moradores mantinham ainda um contrato de trabalho. O assalariamento é uma 
possibilidade de renda acessória na economia familiar, ao passo que a reprodução está atrelada não somente ao salário recebido na empresa, mas também aos produtos cultivados no lote e ao acesso às políticas públicas, como o Programa Bolsa Família e, em alguns casos, à aposentadoria.

No momento em que a empresa iniciou suas atividades, alguns moradores da comunidade foram em busca de emprego na empresa, como o morador G. H. explica:

Eu não pensei de me empregar, tem mais de dez anos que eu não trabalhei mais para patrão, só movimentando no meu trabalho mesmo, porque aqui eu sou dono do meu trabalho, não é? No início, muitos gostaram porque disseram que iam melhorar devido muito emprego, mas aonde foi uma perca, muitos entraram, mas não resistiram [...], não estava acostumado, mas queria trabalhar na empresa. Aí por aí começou, mas agora muitos saíram do emprego, agora têm alguns que vão só (G. H., 44 anos, agricultor, comunicação pessoal, 2016).

Na fala de G. H., nota-se a relação feita entre o trabalho assalariado e o trabalho autônomo no lote; mesmo com a possibilidade de um trabalho acessório, a autonomia do trabalho na própria terra é a alternativa mais segura. Outra questão frequentemente exposta pelos moradores diz respeito às condições de trabalho nos campos de dendê, seja a exploração acentuada da força de trabalho, seja a adequação necessária aos horários da empresa e, consequentemente, o pouco tempo para dedicar-se aos cultivos no lote, condições análogas às apresentadas no estudo de Vilmar et al. (2013). Outro ex-funcionário da empresa explica:

Eu trabalhei um ano e quatro meses na
[empresa], mas o trabalho lá é pesado,
olha. Carreamento, rebaixo, penava ali,
olha, passei um ano e quatro meses ali
quase pra correr, se eles não me tiram, eu
ia sair de lá. É mais pesado que o trabalho
na roça, além do mais que na roça aqui é
difícil também, mas é por conta do cara,
a hora que o cara quiser embora vem e lá
na empresa não, lá o cara está obrigado
lá, tem hora pro cara entrar, hora pro
cara sair, o fiscal toda hora cobrando
produção, meta (I. J., 25 anos, agricultor,
comunicação pessoal, 2016).

I. J.é casado, mas não tem filhos. Ele mora com os pais e outros seis irmãos em meio lote de terra. A pouca terra para trabalhar induz os moradores a procurarem outras formas de trabalho, como o assalariamento. Ao contrário, aqueles que têm terra suficiente e a cultivam com a força de trabalho da família não manifestaram interesse no trabalho assalariado na empresa.

Nota-se, em conversa com os que trabalharam na empresa, um discurso que evoca dignidade e justiça quando se trata do trabalho que lá desempenhavam, como na fala de K. L., que afirma: “não recomendo pra ninguém” (28 anos, agricultor, ex-funcionário da empresa, comunicação pessoal, 2016). Ou na fala de I. J., quando ressalta: "lá você é mandado" (25 anos, agricultor, ex-funcionário da empresa, comunicação pessoal, 2016). 
A forma como os moradores descrevem o trabalho na empresa produz uma imagem, um signo de como é ser "empregado da empresa". Com efeito, forma-se, a partir dos discursos individuais, uma representação coletiva dos moradores em relação à agroindústria. Mesmo aqueles que se relacionam com a empresa por meio do vínculo do assalariamento projetam um discurso de negação em relação a ela. O discurso oculto é compartilhado entre os pares: é produzido pelos moradores ex-funcionários da empresa, na família e, por conseguinte, entre todos os habitantes da comunidade.

Scott (2013) afirma que a subcultura de resistência é formada por um grupo coeso e solidário. "Todos obedecem à mesma autoridade, correm os mesmos riscos, relacionam-se quase exclusivamente uns com os outros e dependem de um elevado grau de solidariedade" (Scott 2013:192). A autoridade é representada por aquele que desempenha a dominação, nesse caso, pela agroindústria de dendê.

O agricultor K. L. conta-nos que foi demitido da empresa após fazer uma reclamação sobre o atraso no horário de almoço, que se vinha repetindo há algum tempo, como relata no depoimento:

Porque o ônibus estava vindo muito tarde pra buscar a gente pro almoço, porque ele ia buscar primeiro outra equipe, então teve dois dias que fomos almoçar quase quatro horas da tarde, aí ninguém nem voltou pro campo nesse horário. Aí na hora, a gente chamou a chefe de área e o gerente, mas o resto da equipe ficou com medo de falar e só eu falei pra eles, aí no outro dia, eu fui demitido (K. L., 28 anos, agricultor, comunicação pessoal, 2016).

É possível perceber que o sentimento de dignidade foi decisivo para que K. L. fosse demitido da empresa. A expressão do sentimento de insatisfação saiu do discurso oculto, ou seja, saiu do espaço de partilha entre os funcionários e dirigiu-se aos chefes, aos representantes da empresa. $\mathrm{O}$ discurso público veio à tona, causando a demissão de K. L., mas, por outro lado, sugeriu a confirmação da dignidade e da justiça.

Scott (2013) afirma que o indivíduo, quando é exposto a um tipo de humilhação ou a uma exploração da força de trabalho, aciona um sentimento de negação dessas condições, o que leva à busca pela afirmação de dignidade $\mathrm{e}$ justiça. Esses sentimentos, no entanto, tendem a sair da esfera do discurso oculto dos grupos subordinados e a "irromper na cena" do discurso público, ante o poder dominante. Como explica Scott (2013:284):

O sentimento de libertação social, de satisfação, de orgulho e de júbilo - apesar de todos riscos que muitas vezes se corre - é uma componente indispensável da forma como esta primeira declaração aberta é experenciada. [...] Como um momento em que a verdade é finalmente revelada [...]. 
As desconfianças sobre o assalariamento decorrem da possibilidade da perda de autonomia sobre o tempo e as decisões de trabalho e também do risco de demissão. Como mencionado por uma moradora, "a [empresa] emprega 100, mas manda embora 200" (M. N., 43 anos, agricultora, comunicação pessoal, 2016). Até o fim da pesquisa, nenhum dos moradores que trabalhou na empresa permaneceu empregado por mais de dois anos. Todos foram demitidos antes de completar esse prazo.

A relação de subordinado à empresa por meio do assalariamento ou, como dizem, "trabalhar pra patrão", especificamente tendo de lidar com o "tempo do relógio da fábrica" para alcançar metas de produção econômica, vai de encontro à ordem pela autonomia e pela penosidade do trabalho em equilíbrio com a satisfação da família. Woortmann (1988:34) explica: "Essas evidências indicam, de forma significativa, que o assalariamento não segue apenas as leis do mercado, mas também as regras da sociedade. Se ele possui uma dimensão econômica, obedece, por outro lado, aos princípios de uma ordem moral".

As exigências em termos de disciplina de trabalho e de tempo de deslocamento, junto com as deficiências no diálogo da empresa moral de produção familiar na terra, caracterizada

com os empregados, chocam-se com a ordem moral dos trabalhadores provenientes da área rural, especialmente das comunidades quilombolas (Saavedra 2017). Enquanto Mota (2005), em estudo sobre trabalhadores rurais em perímetros de irrigação, destaca a valorização dos trabalhadores originários da agricultura familiar pelos empresários locais, a empresa em questão confrontou esses trabalhadores com uma ordem econômica pura, sem considerar as relações sociais entre pessoas, quando os moradores talvez tenham esperado uma articulação entre as duas ordens.

\subsection{RESISTÊNCIA AOS EFEITOS DO CULTIVO DO DENDÊ}

Os moradores relatam que a chegada do dendê fez com que aparecesse na comunidade uma quantidade maior de insetos e animais peçonhentos. Os maruins20 são mosquitos que picam a pele e formam pintas vermelhas que coçam; por conta deles, os moradores começaram a usar calças e camisas de mangas compridas para fazerem suas atividades. A moradora A. B. narra isso como "falta de paz":

Bicho, minha filha, ninguém não está
suportando, esses maruim a gente
passa o dia assim olha, de calça
cumprida, blusa manga cumprida, é
de dia, o dia todo na casa de farinha,
aqui em casa, eu jogo barragem,
baygon, mas não tem jeito, pra gente

20 Nome genérico para diferentes espécies de moscas muito pequenas (menos de quatro milímetros) da família de Ceratopogonidae. As fêmeas de muitas dessas espécies picam para sugar sangue. 
conseguir comer um pouquinho, a gente tem que se esconder, fechar as portas. A gente não tem aquela paz, sabe? (A. B., 56 anos, agricultora, comunicação pessoal, 2016).

O maruim está presente todos os dias, durante o dia, só à noite não aparece. O. P. explica que estava morando sozinho, pois a esposa não suportou conviver com os insetos:

\begin{abstract}
Minha esposa não mora comigo por causa dos bichos, cada ano que passa aparece uma coisa diferente, aí as crianças não acostumam, não. É muito bicho, não tem? É praga demais, aqui tem um bichinho [...], nunca tinha visto esse tipo de bicho, ele dá no luar de madrugada, entra por debaixo do lençol, ferra o cara. É coisa de louco, eu prefiro está trabalhando do que está em casa, porque se ficar parado, Deus o livre (O. P., 39 anos, agricultor, comunicação pessoal, 2016).
\end{abstract}

Além disso, os moradores relatam que frequentemente aparecem cobras, aranhas, lagartas. Os moradores dizem que são as "cobras dos dendezais", cobras com pele de cor avermelhada, identificadas por eles como jiboias, que comem roedores.

Outro descontentamento dos moradores foi em relação à seca do igarapé Cravo. A cabeceira do igarapé fica na altura do $\mathrm{km} \mathrm{40,} \mathrm{passando}$ com vários trechos por dentro da comunidade, especificamente na altura do km 35 e do $\mathrm{km} 37$. Com a compra de terras, a cabeceira ficou dentro da área da empresa e, segundo os moradores, a mata ciliar que a protegia foi desmatada. A moradora Q. R. relata:

\begin{abstract}
Depois do dendê, eu achei mais ruim, fizeram o desmatamento aí que quando chega no verão seca tudo, fica aquela secura aí, pra mim eu acho que é através disso, o dendê puxa muita água. Antes por aqui, a gente não podia nem pisar que era só olho d'água, aqui no canto do esteio saía olho d'água, no fogão saía olho d'água, o poço vazava, a gente pegava água com balde. Mas esse ano retrasado secou que torrou, de cinco em cinco dias meu marido cavava, acho que esse poço já tá com uns 15 metros (Q. R., 39 anos, agricultora, comunicação pessoal, 2016).
\end{abstract}

Outros relatos referem-se aos efeitos dos tratos químicos na manutenção dos dendezais que, segundo os entrevistados, provocam coceiras e vermelhidão na pele, sentidas por crianças do local, o que gerou discordâncias entre moradores e funcionários da empresa. Como o plantio de dendê ficou muito perto das casas dos moradores, o odor dos pesticidas é facilmente sentido, gerando náuseas e prejudicando a respiração. Esses fatos foram também constatados por outros estudos (Gomes et al. 2016; Repórter Brasil 2014).

O discurso público pode ser compreeendido também no caso do uso de pesticidas perto da casa de uma moradora da comunidade. O produto químico é aplicado manualmente pelos funcionários da empresa; mesmo com a aplicação diretamente na palmeira, o odor é facilmente espalhado pelo 
vento. Quando a moradora S. T. estava no período de "resguardo", ou seja, com filho recém-nascido, ela precisou sair de sua casa com o filho e abrigar-se na casa de sua sogra por conta do odor muito forte do produto químico utilizado pelos funcionários da empresa nos campos de dendê.

U. V., o pai de S. T., dirigiu-se até a sede da empresa para notificar o caso aos representantes e pedir que não fosse mais colocado "o agrotóxico nos pés de dendê" que ficam a poucos metros das casas dos moradores. Segundo ele, a empresa "passou a respeitar quanto a isso" (U. V., 56 anos, agricultor, comunicação pessoal, 2016). Nesse sentido, podemos compreender que essas formas de resistência cotidiana servem para reduzir o grau de riscos e perdas aos quais os moradores podem ser submetidos. Sobre isso, Scott (2013:30) ressalta: "Objetivo, afinal, da grande expressão da resistência camponesa não é diretamente derrubar ou transformar o sistema de dominação, mas, sobretudo, sobreviver - hoje, esta semana, esta estação - dentro dele”.

O sofrimento por causa da aplicação de pesticidas, os problemas da seca no igarapé e o aparecimento de insetos, frequentemente mencionados pelos moradores, entram no fator de dominação que foi chamado "efeitos do plantio de dendê".
Outra mudança foi a abertura de ramais por dentro da comunidade ${ }^{21}$, o que, por um lado, facilitou o uso do maquinário na manutenção dos campos de dendê da empresa e, por outro, possibilitou uma melhor mobilidade dos moradores dentro da comunidade, entre localidades próximas, para a rodovia PA-140, bem como para as sedes dos municípios de Bujaru, Concórdia do Pará e Acará, inclusive pelas vans de transporte privado. Os ônibus escolares podem entrar em Castanhalzinho e levar os alunos até a comunidade do Cravo, sem que eles tenham de ir sozinhos pela estrada.

Um dos pontos positivos foi a facilidade para a comercialização da produção agrícola, especialmente o escoamento da farinha. Na roça de inverno, quando se produz uma quantidade maior para a venda e não somente para o consumo da família, os moradores organizam-se, alugam um caminhão e deslocam-se até a feira do município de Marituba (área metropolitana de Belém) para eles mesmos venderem não só a farinha, mas também frutas e verduras. Explica Woortmann (1988:39):

21 Antes da compra, pelos intermediários, das terras nos arredores da comunidade para a implantação de dendê, havia somente um ramal, o do $\mathrm{km} \mathrm{39}$, aberto por máquina. Os ramais do $\mathrm{km} 35$ e do $\mathrm{km} 37$ foram abertos pela empresa e passam pela comunidade. Facilitam a colheita dos frutos e a manutenção dos dendezais realizadas pelos funcionários da empresa. Permitem também o acesso aos campos de dendê além dos limites municipais, ligando áreas dessa monocultura localizadas nos municípios de Bujaru, Concórdia do Pará e Acará. 
na feira "governa" a transformação desse trabalho em ganho, necessário para "botar de um tudo dentro de casa", outro atributo do pai. Neste plano, na feira se afirma a honra do pai, pois quem só pode vender para o patrão, como o morador de engenho, não "governa" o ganho; é sujeito (objeto de sujeição), já que não pode dispor livremente do produto do processo de trabalho, mesmo que este tenha sido realizado autonomamente com base num saber próprio.

Ao mesmo tempo que a empresa de dendê cria possibilidades que facilitam a reprodução do modo de vida dos moradores, suscita também uma ambiguidade por causa das mudanças ocasionadas pela produção de dendê. O território da comunidade não apenas virou rota de passagem dos funcionários da empresa, mas também expôs os moradores à "entrada de estranhos", o que gerou a sensação de insegurança, como explicado no comentário seguinte:

\begin{abstract}
Antes de [da empresa] fazer esse ramal aí, a gente não via certas pessoa varar pra cá, tinha caminho, mas que vinha 35 para cá, não é? Não tinha esses caminho assim, que varavam para essas colônias, assim, não é? E agora, depois que o pessoal [da empresa] fez isso, aí a gente vê muita coisa vindo daí que a pessoa nunca pensava de ver, varar pra aí. Pessoa que a gente não conhece, não sabe o pensar daquela pessoa, achei ruim por isso (W. A., 52 anos, agricultora, comunicação pessoal, 2016).
\end{abstract}

Uma sequência de assaltos em casas que ficaram "isoladas" pelo dendê fizeram com que as famílias se mudassem para outros lugares, para a beira da estrada e para outras comunidades. Foi o caso de cinco famílias localizadas no $\mathrm{km} 42$ da rodovia que se recusaram a vender suas terras à empresa, porém ficaram isoladas em áreas rodeadas pelos dendezais. Para os moradores, esse isolamento, associado à abertura de ramais, facilitou a sequência de assaltos.

Houve o caso de uma família vítima de assalto que teve roupas, utensílios domésticos, compras de supermercado e ferramentas de trabalho subtraídas pelos assaltantes. Nessa ocasião, os moradores da comunidade fizeram um mutirão para adquirir roupas e comida. Depois desse episódio, a família resolveu construir outra casa e, durante a obra, foi acolhida na residência de um dos moradores, o que confirma a existência de reciprocidade unilateral entres eles, caracterizada pela ajuda a pessoas em situação de dificuldade.

Podemos verificar que a agroindústria, nesse sentido, provocou rearranjos que permitiram aos moradores a criação de novas práticas, caracterizadas pela dualidade de sentimentos: melhoria e insatisfação ao mesmo tempo. Os ramais, em um sentido mais específico, deixaram a comunidade suscetível à entrada de estranhos, mas também permitiram aos moradores utilidades que antes não existiam. 


\subsection{RESISTÊNCIA AO IMPEDIMENTO DO ACESSO AO ENTORNO PELA DESVALORIZAÇÃO DO OPONENTE}

Outra mudança sentida pelos moradores foi a derrubada da vegetação que ficava no entorno da comunidade $^{22}$, o que provocou o afugentamento da caça para áreas mais distantes. Além disso, a circulação dos moradores na área que hoje pertence à empresa já não se dá com tanta liberdade, como explicado no seguinte comentário:

Irmã, finalmente do dendê aqui eu não tenho pra falar, só que tem uma coisa assim pra me falar, que eles têm ciúme do que é deles, mas eles andam no que é da gente. Logo quando eles entraram aqui, eles queriam proibir os meninos de pegarem esse negócio de curió, né? Eles falaram pra eles que eles compraram os terrenos, mas não compraram os curió, os curió Deus que tinha colocado no lugar. Não gostam que tire os bichos do mato pra comer, né? Mas eles compraram a terra, não compraram os bichos, os bichos foi Deus que deixou, né? (E. F., 70 anos, aposentada, comunicação pessoal, 2016).

Com a compra de terras pela agroindústria, houve a proibição da entrada dos moradores na área da Reserva Legal da empresa. Essa privação também impede que os moradores utilizem a área para a caça, como disse uma moradora: "eles não gostam que a gente ande no que é deles, mas eles andam no que é nosso". Esse "não gostar" está associado ao fato de que há uma intimidação por parte dos fiscais da empresa, segundo os moradores, "toda vez que tem alguém por lá, às vezes procurando o que caçar, né? Eles ficam perguntando o que estão fazendo" (E. F., 70 anos, aposentada, comunicação pessoal, 2016).

Esses relatos denotam um conflito entre funcionários da empresa e os moradores e reforçam o sentido de pertencimento e de direito sobre aquilo que a mata pode oferecer aos que vivem na comunidade. Antes da compra pela agroindústria das terras que ficam no entorno do Castanhalzinho, os moradores do local tinham o costume de retirar madeira da mata ${ }^{23}$, tanto para fazer estacas para o plantio da pimenta, como para construir suas casas. Os antigos donos das terras, que eram fazendeiros, não limitavam essa prática, pelo contrário, costumavam pagar os moradores para a retirada dessas estacas, pois serviam para o próprio plantio de pimenta do contratante.

Moradores mais velhos da comunidade, como G. H., B. C. e H. I., disseram a seguinte frase durante uma das conversas em campo: “a [empresa] está falindo”. $\mathrm{Na}$ conversa com esses três moradores, eles contaram que a empresa diminuiu o ritmo de trabalho, que cada vez mais pessoas são demitidas e que "nem se vêmais passar funcionário pro dendê". B. C. explicou: "Está acabando

22 Os moradores do local explicaram que, antes da aquisição das terras pela agroindústria de dendê, os antigos donos desenvolveram nelas atividades ligadas à pecuária. Porém, em algumas áreas dessas terras, havia uma vegetação secundária alta que foi removida com a implantação do dendê.

23 Há uma área de Reserva Legal nas terras adquiridas pela empresa, na qual não pode ser desenvolvida a atividade econômica. 
já, eles fizeram tanta plantação desse dendê e agora não deram conta, vai acabar isso aí, a gente vê esses dendê tudo seco, mato está cobrindo, eles nem cuidam mais" (B. C., 75 anos, aposentado, comunicação pessoal, 2016).

Essa constatação assume a forma de rumores e boatos, que vão sendo compartilhados por todos os moradores. Rumores e boatos são meios elementares de disfarce, pois “[...] não permitem discernir qualquer autor identificável” (Scott 2013:205). Boatos e rumores sobre a "falência" da empresa servem para justificar a retirada de estacas para o plantio da pimenta-do-reino na área de mata da empresa.

Nessa situação, os moradores, na época do plantio da pimenta, resolveram criar um grupo para a retirada de estacas, grupos de homens, todos da comunidade. Organizaram-se para o aluguel de uma caçamba, derrubaram as árvores específicas e "bateram as estacas" para o uso individual nos seus respectivos lotes. Isso mostra "[...] os esforços que desenvolvem para contrariar a apropriação material [...]" (Scott 2013:20) dos recursos naturais aos quais tinham acesso anteriormente, hoje em posse da empresa.

Isso lembra o que Scott (2013) chama "discurso oculto enquanto prática”. Nesse caso, a retirada das estacas em uma área sob o domínio da empresa traduz um “[...] sentido de justiça popular que não podia ser abertamente afirmado e um conjunto de práticas desenvolvidas para procurar exercer esses direitos de forma clandestina” (Scott 2013:261).

\section{CONSIDERAÇÕES FINAIS}

O tema deste artigo são as formas de resistência à agroindústria do dendê na mesorregião do nordeste paraense, especificamente na comunidade quilombola do Castanhalzinho, em Concórdia do Pará. No âmbito das políticas governamentais de fomento à produção de agrocombustíveis, o discurso público do dominante expressa-se por meio da promessa de inclusão da agricultura familiar pela integração produtiva à agroindústria e pela criação de empregos nos monocultivos de dendê da empresa. Soma-se a isso o discurso da sustentabilidade e da distribuição de renda aos atores que trabalham no campo.

A implementação das agroindústrias de dendê, em particular da empresa em questão, provocou novos arranjos nas comunidades rurais localizadas em sua área de influência. Por um lado, constatamos a saída de moradores por conta das transformações na paisagem e dos efeitos da dendeicultura (animais peçonhentos, mosquitos, uso de pesticidas nas proximidades, entrada de estranhos por causa da abertura de ramais). Por outro, há contraditoriamente a permanência no território e a volta dos que perderam emprego em Belém porque os ramais abertos pela empresa permitem uma maior mobilidade dos moradores e facilitam o escoamento da produção, como também a entrada de veículos para o transporte das pessoas (vans).

Inspirados em Scott(2013), constatamos que existe uma resistência cotidiana dos moradores da comunidade 
por meio do discurso oculto - discursos, gestos, práticas e fofocas - que cria um signo, uma imagem da empresa, discurso que é compartilhado pelos moradores e dá uma ideia coletiva da agroindústria, numa relação que é "[...] uma luta material em que ambas as partes procuram constantemente detectar fragilidades e explorar pequenas vantagens” (Scott 2013:254).

Concluímos que as principais formas de resistência foram a negação de venda das terras, que incluiu uma manifestação aberta pela mobilização das associações quilombolas, a rejeição das regras do assalariamento, o discurso sobre os efeitos do dendê (contaminação pelos pesticidas, seca do igarapé e desaparecimento da caça por causa do desmatamento para o plantio das monoculturas), o que levou até a uma intervenção pessoal para solicitar mais respeito, e o acesso clandestino aos recursos no entorno, anteriormente permitido. Nos dois momentos relatados aqui, as manifestações públicas não chegaram a ser um desafio do dominante, ao contrário do assalariado, que questionou a conduta da empresa e foi demitido. A resistência cotidiana baseiase na coesão do grupo garantida pelas características desse campesinato: a reciprocidade, a religiosidade, o parentesco, bem como a autonomia no trabalho. Esses elementos permitem criar um vínculo sólido entre os atores, por meio das constantes trocas de alimentos, de roupas e também do trabalho na roça e no retiro entre as famílias em redes de reciprocidade constituídas ao longo dos anos, as quais assumem maior intensidade em épocas de sofrimento e de adversidade. Nessas, o suporte religioso também se evidencia independentemente das suas diferenças.

Podemos compreender que os dois agentes antagonistas, a empresa e os moradores do local, disputam um território, cada um possuindo mecanismos de apropriação e de defesa dos seus ideais. Há uma resistência cotidiana por parte dos moradores como forma de continuarem no território, de resistirem aos efeitos da dendeicultura e a seus mecanismos de dominação.

Scott (2013) explica que o discurso público do dominante é utilizado para a afirmação da imagem de poder efetivo e para a justificação de suas práticas de dominação. Esse discurso público abrange falas, gestos e práticas. A partir dessa compreensão, verificamos que a agroindústria utiliza-se dos seguintes elementos de dominação: compra de terra, integração por contrato, assalariamento e efeitos do plantio de dendê (mudanças no território da comunidade). Em contrapartida, a resistência cotidiana dos moradores manifesta-se no discurso oculto por gestos, falas e ações para a manutenção do território sem submissão aos efeitos da dendeicultura e aos mecanismos de dominação de grupos mais poderosos.

A partir da elucidação desses processos, esperamos, com este artigo, inspirar outros grupos e suscitar discussões críticas e a produção de novos conhecimentos. 


\section{REFERÊNCIAS}

Acevedo Marin, R. 2010. Estratégias dos quilombolas de Jambuaçu e projetos da Vale S. A. no Moju, Pará, in Cadernos de debates Nova Cartografia Social: Territórios quilombolas e conflitos. Organizado por A. F. B. de Almeida, R. Acevedo Marin, R. Cid, C. B. Müller, e E. de A. Farias Júnior, pp. 49-61. Manaus: Projeto Nova Cartografia Social da Amazônia / UEA Edições.

Acevedo Marin, R. E., e M. Backhouse. 2014. Guerra do dendê: quilombolas atingidos pela expansão do dendê no Pará. Manaus: UEA Edições. (Boletim Informativo 9).

Almeida, M. W. B. de. 1986. Redescobrindo a família rural. Revista Brasileira de Ciências Sociais 1(1):66-93.

Aquino, S. L. de. 2013. Sobre agricultores, cultivo de eucalipto e estratégias agroindustriais: resistir e adaptar-se ao sistema de produção integrada. Tese de Doutorado, Pós-graduação em Ciências Sociais, Universidade Federal Rural do Rio de Janeiro, Rio de Janeiro.

Backhouse, M. 2013. A desapropriação sustentável da Amazônia: o caso dos investimentos em dendê no Pará. Berlin: Freie Universität Berlin. Fair Fuels? Working Paper 6.

Brandão, F., e G. Schoneveld. 2015. The state of oil palm development in the Brazilian Amazon: trends, value chain dynamics, and business models. Bogor, Indonesia: Center for International Forestry Research. (Working Paper 198).

Brandão, F., G. Schoneveld, e P. Pacheco. 2018. Integração da agricultura familiar à cadeia da palma de óleo na Amazônia Brasileira: análise e recomendações. Bogor, Indonesia: Center for International Forestry Research. (Infobrief 105).

Brasil. 1988. Constituição da República Federativa do Brasil. Brasília, DF: Senado Federal. 
Brasil. 2010. Projeto de lei. Dispõe sobre a criação do Programa de Produção Sustentável da Palma de Óleo no Brasil, estabelece diretrizes para o zoneamento agroecológico para a cultura de palma de óleo, e dá outras providências. Brasília: Congresso Nacional. Disponível em: http://www.camara.gov. br/proposicoesWeb/prop_mostrarintegra?codteor=768113. Acesso em: 1 jul. 2020.

Cardoso, C. F. S. 1982 [1979]. Agricultura, escravidão e capitalismo. 2. ed. Petrópolis: Vozes.

Cleary, D. 1998. "Lost altogether to the civilised world": race and the Cabanagem in Northern Brazil, 1750 to 1850. Comparative Studies in Society and History 40(1):109-135.

CPISP. 2020. Observatório terras quilombolas. São Paulo: Comissão Pró-Índio de São Paulo. Disponível em: http://cpisp.org.br/direitosquilombolas/observatorio-terras-quilombolas/?terra_ nome $=\&$ situacao $=269 \& u f \% 5 B \% 5 \mathrm{D}=49 \&$ ano_de $=\&$ ano_ate $=\&$ orgao_exp=0. Acesso em: 6 jul. 2020.

Cueva, O. de la T. 2011. Freedom in Amazonia: the black peasantry of Pará, Brazil, 1850-1950. Doctoral Thesis, School of Arts and Sciences, University of Pittsburgh, Pittsburgh.

Eder, K. 2003. Identidades coletivas e mobilização de identidades. Revista Brasileira de Ciências Sociais 18(53):5-18.

FCP. 2020. Certidões expedidas às comunidades remanescentes de quilombos (CRQs) atualizada até a portaria $n^{\circ}$ 96/2020, publicada no DOU de 12/05/2020. Brasília: Fundação Cultural Palmares. Disponível em: http://www.palmares.gov.br/?page_id=37551. Acesso em: 2 jul. 2020.

Florentino, M., e M. Amantino. 2012. Fugas, quilombos e fujões nas Américas (séculos XVI-XIX). Análise Social 47(203):236-267.

Gomes, D. L., F. C. da Silva, e C. O. Macedo. 2016. Expansão territorial do dendê e resistência camponesa no nordeste paraense. Caminhos de Geografia 17(57):191-200. 
Guedes, A. C. F. 2014. Adesão das famílias camponesas à produção da palma de óleo nos municípios de Moju e Concórdia do Pará: estratégia de parceria das empresas AGROPALMA e BIOPALMA. Dissertação de Mestrado, Pós-graduação em Serviço Social, Universidade Federal do Pará, Belém.

IBGE. 2020. Concórdia do Pará. Rio de Janeiro: Instituto Brasileiro de Geografia e Estatística. Disponível em: https://cidades.ibge.gov.br/brasil/pa/concordia-do-para/panorama. Acesso em: 1 jul. 2020.

Linhares, M. Y., e F. C. T. da Silva. 2009 [1981]. A questão da agricultura de subsistência (1981), in Camponeses brasileiros: leituras e interpretações clássicas. Organizado por C. A. Welch, E. A. Malagodi, J. S. B. Cavalcanti, e M. de. N. B. Wanderley, pp. 117-133. São Paulo: Editora Unesp; Brasília, DF: Núcleo de Estudos Agrários e Desenvolvimento Rural.

Macedo, C. O., e R. B. de Sousa. 2015. Novos projetos, velhas práticas: os impasses entre agricultura camponesa e agronegócio do dendê em terras amazônicas. Tempos Históricos 19(1):302-331.

Macedo, C. O., e R. B. de Sousa. 2016. Camponeses e religiosidade na Amazônia Paraense. Revista Terceira Margem Amazônia 2(6):41-71.

Malcher, M. A. F. 2011. Territorialidade quilombola no Pará: um estudo da comunidade São Judas, município de Bujaru e da comunidade do Cravo, município de Concórdia do Pará. Dissertação de Mestrado, Pós-graduação em Geografia, Universidade Federal do Pará, Belém.

Malcher, M. A. F. 2017. O olhar geográfico: a formação e territorialização de comunidades quilombolas no município de São Miguel do Guamá, Pará. Tese de Doutorado, Pós-graduação em Geografia, Universidade Federal do Ceará, Fortaleza.

Menezes, M. A. de. 2002. O cotidiano camponês e a sua importância enquanto resistência à dominação: a contribuição de James C. Scott. Raízes 21(1):32-44. DOI: https://doi.org/10.37370/raizes.2002.v21.177 
Mota, D. M. da. 2005. Trabalho e sociabilidade em espaços rurais. Fortaleza: Banco do Nordeste do Brasil; Embrapa Tabuleiros Costeiros.

Norwana, A. A. B. D., R. Kunjappan, M. Chin, G. Schoneveld, L. Potter, e R. Andriani. 2011. The local impacts of oil palm expansion in Malaysia: an assessment based on a case study in Sabah State. Bogor, Indonésia: Center for International Forestry Research. (Working Paper 78).

Nunes, F. A. 2009. Núcleos coloniais e agricultura na Amazônia Imperial: uso e ocupação da terra. Revista Espaço Acadêmico 9(100):70-76.

Pará. 2018. Com 53 áreas tituladas, Pará é o Estado que mais reconhece comunidades quilombola. Belém: Secretaria de Estado de Planejamento. Disponível em: https://www.seplan.pa.gov.br/com-53\%C3\%A1reas-tituladas-par\%C3\%A1-\%C3\%A9-o-estado-que-mais-reconhece-comunidades-quilombolas. Acesso em: 1 jul. 2020.

Peabiru. 2020. Quem são as comunidades quilombolas no Pará? Direito à terra e reconhecimento. Belém. Instituto Peabiru. Disponível em: https://peabiru.org.br/2020/04/24/quem-sao-as-comunidadesquilombolas-no-para-direito-a-terra-e-reconhecimento/. Acesso em: 6 jul. 2020.

Pontes, D. L. R., e G. A. D. Guerra. 2016. Resistência camponesa: duas abordagens para um conceito. Raízes 36(1):50-60.

Potter, L. 2008. Dayak resistance to oil palm plantations in West Kalimantan, Indonesia. Anais do XVII Biennial Conference of the Asian Studies Association of Australia. Disponível em: http://citeseerx.ist. psu.edu/viewdoc/download?doi=10.1.1.395.2179\&rep=rep1\&type=pdf. Acesso em: 1 jul. 2020.

Reis, J. J, e F. dos S. Gomes. 1996. Organizadores. Liberdade por um fio: história dos quilombos no Brasil. São Paulo: Companhia das Letras. 
Repórter Brasil. 2014. Instituto Evandro Chagas detecta contaminação por agrotóxicos na Região de Expansão do Dendê no Pará. São Paulo: Centro de Monitoramento de Agrocombustível. Disponível em: https://reporterbrasil.org.br/2014/09/instituto-evandro-chagas-detecta-contaminacao-por-agrotoxicosna-regiao-de-expansao-do-dende-no-para/. Acesso em: 1 jul. 2020.

Saavedra, M. da P. C. 2017. O "ir" para o assalariamento na agroindústria do dendê e o "voltar" para a comunidade quilombola: o caso de Santo Antônio em Concórdia do Pará. Dissertação de Mestrado, Pós-graduação em Sociologia e Antropologia, Universidade Federal do Pará, Belém.

Sampaio, I. C. 2014. A agricultura familiar e a agroindústria do dendê no município de Tomé-Açu (PA): efeitos da agricultura por contrato na produção e no trabalho familiar. Dissertação de Mestrado, Pós-graduação em Sociologia e Antropologia, Universidade Federal do Pará, Belém.

Santana, R. M. 2010. Os caminhos da regularização fundiária no município de Concórdia do Pará. Dissertação de Mestrado, Pós-graduação em Geografia Humana, Universidade de São Paulo, São Paulo.

Schrier-Uijl, A. P., M. Silvius, F. Parish, K. H. Lim, S. Rosediana, e G. Anshari. 2013. Environmental and social impacts of oil palm cultivation on tropical peat: a Scientific Review, in Reports from the Technical Panels of the 2nd Greenhouse Gas Working Group of the Roundtable on Sustainable Palm Oil (RSPO), Editado por T. J. Killeen e J. Goon, pp. 131-168. RSPO.

Scott, J. C. 1985. Weapons of the weak: everyday forms of peasant resistance. New Haven; London: Yale University Press.

Scott, J. C. 2002. Formas cotidianas da resistência camponesa. Trad. M. Menezes; L. Guerra. Raízes 21(1):10-31.

Scott, J. C. 2013. A dominação e a arte da resistência: discursos ocultos. Apres. Fátima Sá. Trad. Pedro Serras Pereira. Lisboa: Livraria Letra Livre. 
Silva, F. C., J. M. O. Silva, e C. O. Macedo. 2016. Quilombolas e agronegócio do dendê em disputa pelo território no Alto Acará-PA, in Os “nós” da questão agrária na Amazônia. Organizado por C. O. Macedo, F. O. Bringel, R. B. Sousa, e R. M. Santana, pp. 169-189. Belém: Editora Açaí.

Sirait, M. T. 2009. Indigenous peoples and oil palm plantation expansion in West Kalimantan, Indonesia. Indonesia Country Report prepared for the study: Environmental degradation, natural resources and violent conflict in indigenous habitat in Kalimantan-Indonesia.

Sousa, R. B. de. 2018. Recriação camponesa e o agronegócio do dendê no nordeste paraense. Tese de Doutorado, Pós-graduação em Geografia, Universidade Federal Fluminense, Niterói.

Sousa, R. B., e C. O. Macedo. 2011. Comunidades camponesas no nordeste paraense: o caso de São Judas e Cravo. Geografia Londrina 20(2):115-128.

Tavares, M. G. da C. 2008. A formação territorial do espaço paraense: dos fortes à criação de municípios. Revista ACTA Geográfica 2(3):59-83.

Thury, J. P. C. 2017. Tensões territoriais na Amazônia paraense: o povo indígena Tembé-Turé-Mariquita no município de Tomé-Açu. Dissertação de Mestrado, Pós-graduação em Geografia, Universidade Federal do Pará, Belém.

Timone-Martinez, E. 2013. La culture du palmier à huile en région amazonienne: entre acceptation, résignation et résistance. Dissertação de Mestrado, Master Sciences et Techniques du Vivant et de l'Environnement - Mention Espaces, Ressources, Milieux, AgroParisTech, Paris.

Treccani, G. D. 2006. Terras de quilombo: caminhos e entraves do processo de titulação. Belém: Secretaria Executiva de Justiça, Programa Raízes. Disponível em: http://www.direito.mppr.mp.br/arquivos/File/ Girolamo.pdf. Acesso em: 1 jul. 2020. 
USDA. 2020. Palm Oil Production by Country in 1000 MT. Disponível em: https://www.indexmundi. com/agriculture/?commodity=palm-oil. Acesso em: 1 jul. 2020.

Vilmar, M. L., J. Sousa, L. Arruda, e R. Rodrigues. 2013. O comportamento sócio-trabalhista na produção do óleo de palma do dendê no Estado do Pará com foco nas empresas Agropalma, Biovale/Biopalma, Petrobras Combustíveis. São Paulo: Instituto Observatório Social. Relatório final. Disponível em: http:// www.observatoriosocial.org.br/?q=biblioteca/o-comportamento-socio-trabalhista-na-producao-dooleo-de-palma-do-dende-no-estado-do-pa-0. Acesso em: 1 jul. 2020.

Woortmann, K. 1988. “Com parente não se neguceia”: o campesinato como ordem moral. Anuário Antropológico 12(1):11-73. 